\title{
How Does Voluntary Contact with the Police Produce Distrust? Evidence from the French Case
}

\author{
Victor Le Franc ${ }^{1, *}$ and Alexis Spire ${ }^{2}$ \\ 1 UFR des Sciences Sociales, Université de Versailles Saint-Quentin-en-Yvelines, 78000 Versailles, France \\ 2 National Center for Scientific Research (CNRS), 75000 Paris, France; alexis.spire@ehess.fr \\ * Correspondence: victor.le-franc@ens.uvsq.fr
}

Citation: Le Franc, Victor, and Alexis Spire. 2021. How Does Voluntary Contact with the Police Produce Distrust? Evidence from the French Case. Social Sciences 10: 399. https:// doi.org/10.3390/socsci10100399

Academic Editor: Andreas Pickel

Received: 23 September 2021

Accepted: 9 October 2021

Published: 16 October 2021

Publisher's Note: MDPI stays neutral with regard to jurisdictional claims in published maps and institutional affiliations.

Copyright: (c) 2021 by the authors. Licensee MDPI, Basel, Switzerland. This article is an open access article distributed under the terms and conditions of the Creative Commons Attribution (CC BY) license (https:/ / creativecommons.org/licenses/by/ $4.0 /)$.

\begin{abstract}
Drawing on quantitative and qualitative data, this article points out the effects that instances of contact with the police can produce on the relationship with this public institution. The quantitative analysis highlights that trust in the police depends on social variables, such as political orientation, level of resources, age, and religion, but also on the frequency of direct contact with this institution. Being summoned to a police station is significantly associated with distrust in the police, and selfinitiated contacts also promote distrust toward the police. Our qualitative data, collected through participant observation and interviews, provide a further insight into these results. The interaction between the police and governed people has two dimensions that may explain the production of distrust. On the one hand, the interaction involves a relationship of domination by the police, which is manifested by a demand on the part of the police for docility from the complainants. On the other hand, it involves a relationship of service, which gives rise to an expectation of recognition on the part of governed people, an expectation that is rarely satisfied. These everyday interactions do not necessarily translate into judgments about the fairness of police officers. Such feelings of frustration and dispossession should be taken into consideration in understanding how trust is affected by these voluntary contacts.
\end{abstract}

Keywords: voluntary contacts; social characteristics; trust

\section{Introduction}

In France, several recent events have put the issue of the relationship between the police and citizens back at the heart of public debate: the repression of the "Gilets jaunes" (yellow vest) movement has called into question the confidence of demonstrators in the police force, and the "Black Lives Matter" movement, originating in the United States, has served as a reminder that racial discrimination also exists in Europe. This focus on the repressive dimension of police action has left unexplored the role of the police as services providers. According to Tyler (1990), the more that people perceive the police to behave fairly, the more they will trust them and the more willing they will be to cooperate with them: the population's trust in the police institution derives from police officers' ability to convince people of the honesty and rectitude of their own conduct. Tyler later went on to formulate a more general proposition: if individuals are to cooperate with the police, the objectives of leaders of the police must be demonstrably fair and honest (Tyler 2011b). This theory of procedural justice inspired a whole series of studies on the topic of compliance with the law (Johnson et al. 2014). Many studies in this area focus on the dimension of controlling populations, although this is far from being the only function of the police institution-it is also a public service that can be called upon in the event of a dispute or conflict with family members, neighbors, or strangers. Attitudes toward the police cannot be judged solely by reference to the interactions arising from identity checks, which, in France, represent only a tiny minority of interactions with the police. For the vast majority of the population, trust in the police is built up through a set of experiences with the police institution, a process that continues throughout a person's life. In the present study, we 
view the police not in their role as a repressive force but rather in their role as a service provider and potential intermediary in disputes. We will demonstrate that the way in which individuals relate to the police is shaped by certain sociodemographic factors but that it can also evolve in response to cumulative, first-hand experiences of using police services. We will also describe police contacts in order to argue that self-initiated contacts can be understood as bureaucratic encounters.

\section{Literature Review}

Throughout the history of procedural justice theory, there have been many studies that place the concept of trust at the very heart of their analysis of public-police relations (Tyler 2011a). This theoretical framework has been empirically tested in various national contexts, including Belgium (Van Craen and Skogan 2014), the United Kingdom (Yesberg and Bradford 2018), Hungary (Boda and Medve-Bálint 2017), China (Zhang et al. 2018), and, indeed, France (Roché 2016). Some authors have sought to open up the "black box" of the concept of trust itself ( $\mathrm{Wu}$ and Sun 2009), demonstrating that the public's judgments relating to police officers' fairness and rectitude carry greater weight than perceptions of their effectiveness (Jackson and Bradford 2009). Trust in the police is not only an impersonal relationship: it requires proof of recognition (Vitale 2009), and it remains closely linked to the social resources that can be used by the actors involved.

The principal limitation encountered by studies based on statistical sources is the great difficulty of judging whether, on the one hand, the belief that police officers will behave fairly leads to feelings of trust, or, on the other hand, feelings of trust lead to positive assessments of police behavior (Roché 2017, p. 108). Our aim in this paper is to study the public-police relationship in a way that takes into account the practices and cumulative experiences of direct interactions with the police institution. From this perspective, trust in the police can be understood as a product of (a) sociodemographic factors and (b) a succession of lived experiences of contact with law enforcement.

For our enquiry, we observed individuals at the point when they visited police stations in order to make a complaint, thereby interacting with police officers, whose role is to make a legal judgment about the events related to them so that the matter can be referred to the courts. Individuals who appeal to the police on their own initiative tend to have more favorable attitudes toward the police than those whose dealings with the institution are forced upon them (Rosenbaum et al. 2005). In this respect, the police's capacity to fulfil users' expectations may prove to be a decisive factor affecting individuals' future attitude toward the police (Van Craen and Skogan 2014). By observing interactions between complainants requesting assistance from the police institution and the officers attending to them, we can observe an often-neglected dimension of this encounter: the capacity of the police institution to present itself as a source of protection rather than as a repressive force. We argue that the analysis of self-initiated encounters should take into account the fact that individuals seek social recognition in the course of their social relations with others.

The effects of vexatious police behavior and the respect for the community/communities manifested by the police have been well understood for some time, having been studied since the early days of research on the police (Wilson 1968; Reiss 1971). Most authors base their conclusions on responses to abstract situations presented to respondents as scenarios, noting that not everybody agrees on what is fair (Waddington et al. 2015). Our analysis is based on real situations experienced first-hand rather than being observed at a distance.

A central theme in the study of procedural justice is the attempt to identify the attitudes underlying an individual's sense of injustice (Tyler and Huo 2002). Several studies have shown that there is a very strong link between personal experience and levels of trust in the police (Reisig and Chandek 2001; Skogan 2006; Myhill and Bradford 2012). Some have even argued that personal experience carries greater weight than an individual's social characteristics (Skogan 2005) or race (Li et al. 2016). It is now well established that levels of trust are lower among those who have had recent contact with the police (Bradford et al. 2009; Van Damme 2017). 
In most of this research, the concept of "contact" remains obscure: it is very difficult to determine the precise nature of a given interaction, how it was interpreted by those involved, and what impact it had on someone's attitude toward the police. The literature that has grown up around Tyler's theory tends to reduce individual attitudes to binary choices or lists of variables that are thought to play a part in how people relate to the police institution. Here, our aim is to show that trust is the product of (a) a set of sociodemographic factors that shape attitudes toward the police in general and (b) the sum of lived experiences amassed over the individual's life. These two dimensions can be addressed by describing how judgments arising from a specific encounter with the police become integrated into prior beliefs that had been formed at a distance and/or in previous encounters.

The original contribution of our study consists in gauging trust in the police based on three kinds of data gathered in conjunction with one another: a statistical questionnaire, a participant observation, and a series of in-depth interviews. Our aim is to show that, in France, distrust toward the police is correlated with individuals' social characteristics and the frequency of their contact with the police institution. We also hypothesize that trust depends on the ability of the police institution to provide recognition to the governed people.

\section{Materials and Methods}

In this paper, we turned to mixed methods to understand how direct contact shapes individuals' trust in the police. Qualitative data helped us to interpret and explain quantitative findings.

The quantitative data come from the PROFET survey (Pratiques et représentations ordinaires face à l'État), based on a statistical questionnaire belonging to the ELIPSS panel study (Étude Longitudinale par Internet Pour les Sciences Sociales) carried out by the Center for Socio-Political Data (CDSP). In January 2017, in the framework of the ELIPSS panel study, a questionnaire encompassing various modalities of individual relationships to the police was administered to a sample of 2676 respondents. The sample was designed to be representative of the resident population of mainland France aged between 18 and 75 . Respondents were selected randomly from a list of households provided by the Institut National de la Statistique et des Études Économiques (INSEE). Participants were provided with a touch-screen tablet and an internet subscription in exchange for their cooperation in responding to a monthly questionnaire (this survey method may account for the unusually high response rate of $90 \%$ ). The aim was to achieve a quantitative assessment of the relationships that people develop with various public institutions: tax authorities, primary and secondary schools, law enforcement, and the courts.

The qualitative data on trust in the police, on which this study draws, emerged from fieldwork undertaken in 2019 in two police stations in a large town of 110,000 inhabitants in northern France. This work was concerned with users of police services arriving at the station in order to make some kind of complaint, excluding reports of homicide, physical violence, and sexual assault. Researchers positioned themselves in the station waiting room and asked individuals if they would consent to being observed while making their complaint. An initial phase of the qualitative study yielded observational data collected in the waiting room and during face-to-face exchanges between complainants and officers at the reception desk. In a second phase, we carried out fifteen semi-structured interviews (Table 1) with complainants whom we had met in the observation phase in the two police stations who were willing to answer our questions, often later in the week, to discuss their experience at the police station. Before the meeting, we asked the participants orally whether they consented for the interviews to be used for academic purposes. 
Table 1. Interview participants' social characteristics.

\begin{tabular}{ccccc}
\hline Interview & Gender & Age & Occupation & $\begin{array}{c}\text { Motive of } \\
\text { Complaint }\end{array}$ \\
\hline 1 & Man & 30 & White-collar worker & Marital conflict \\
\hline 2 & Woman & 40 & Care giver & Harassment \\
\hline 3 & Man & 18 & High school student & Theft \\
\hline 4 & Woman & 18 & Nursing school student & Scam \\
\hline 5 & Woman & 21 & Communication student & Scam \\
\hline 6 & Man & 22 & Temporary worker & Burglary \\
\hline 7 & Woman & 30 & Unemployed & Harassment \\
\hline 9 & Woman & 30 & Former care giver & Scam \\
\hline 10 & Man & 33 & Manual worker & Scam \\
\hline 11 & Man & 33 & Manual worker & Scam \\
\hline 12 & Man & 22 & Commercial engineer & Theft \\
\hline 13 & Man & 36 & Social housing manager & Urban deprivation \\
\hline 14 & Man & 47 & Computer professional & Theft \\
\hline 15 & Woman & 48 & Insurance employee & Theft \\
\hline Wote: The respondenan & 50 & Social security manager & Theft \\
\hline Woman & 60 & Nurse & Harassment \\
\hline
\end{tabular}

\section{Analysis}

This study uses a logistic model to test the relationship between trust and police contacts. The selection of control variables was based on the literature. We then built a model retaining four social characteristics variables. The model we estimated was:

logit $($ trust in the police $)=\alpha+\beta 1($ religion $)+\beta 2($ political orientation $)$ $+\beta 3$ (police contact) $+\beta 4$ (economic resources) $+\beta 5$ (age)

Owing to its national history, France has long been a so-called "color-blind society", in the sense that ethnicity is not considered as a legitimate criterion for group description, either in an administrative or academic context, and the gathering of such data has been legally restricted. As a result, this category is not visible in any public policy or law, nor in census data (Wacquant 1993, p. 374). In the absence of the ethnicity criterion, we were nevertheless able to take into account nationality and religious affiliation in our survey. The criterion of nationality appeared to be a non-significant variable, but religious affiliation proved to be a significant predictor of trust in the police. The religion variable was divided into five modalities (Catholic, Muslim, no religion, Protestant, and other) (1), political orientation was divided into three modalities (left-wing, centrist, and right-wing) based on the self-positioning of participants on a political spectrum consisting of seven choices (2), police contact was divided into four modalities (self-initiated contacts, police summonses, police stops, and no contact) differentiating different types of encounter with the police (3), the economic resources variable was divided into four groups based on information on individuals' monthly resources (4), and age was divided into five groups differentiating generations (5). The estimates were calculated on a population of $\mathrm{N}=2612$, as 45 people who refused to answer all the questions were excluded as well as 19 people who refused to answer the question on trust.

The interviews explored the process of making a complaint to the police before moving into a broader discussion of respondents' various relationships with the police institution. The aim of these interviews was not only to record respondents' moral and political 
judgments with respect to the police in the abstract but also to understand how these judgments are connected with direct interactions with police services. We focused on four cases that illustrated various attitudes toward the police. Observations were made on the basis of notes taken directly while waiting in the police station or during interviews between the police and the complainants.

\section{Results}

As in most European countries, in France, the police enjoy more public trust than any other public institution: according to our statistical survey, $79 \%$ of those questioned stated that they had "quite a lot" or "total" trust in the police. The confrontation of quantitative findings and qualitative data collected in in-depth interviews with complainants met at the police station allows us to shed light on the link between direct contacts and trust in the police.

\subsection{Police Contacts: The Negative Effect of Contacts on Trust}

According to the results of our survey, more than a third (36\%) of the population has had some interaction with the police in the last two years. While public debate tends to fixate on identity checks, the vast majority of encounters with law enforcement occur when an individual visits a police station to carry out a certain task. The majority of interactions arise from complaints or requests for police intervention (59\%), whereas fewer interactions arise from roadside checks (4\%), summonses $(4 \%)$, and a handful of other matters (for example, information requests, powers of attorney, car accidents, or neighbor disputes).

Among those who have had no contact with the police, $83 \%$ trust this institution, while for those who have had two or more contacts, only $72 \%$ trust it (Spire 2020). This is the result that needs to be explained: having had two or more contacts with law enforcement in the past two years is connected to a lower level of trust in the police than having had no contact with them.

Table 2 provides results regarding the effects of social characteristics on trust, controlling for experiences of direct contact with the police. Four sociodemographic variables appeared to be insignificant with regard to trust in the police in France: gender, nationality, possession of a high school diploma, and occupational group. On the other hand, political values appear to be significant predictors of trust in France. All other things being equal, the probability of an individual expressing trust in the police is lower among those who regard themselves as being on the left of the political spectrum $(\mathrm{OR}=-1.36 ; p=0.014)$ than it is among those at the center of the political spectrum. This finding echoes the already well-established relationship between conservative values and trust in the police (Stack and Cao 1998). Along with the army, the police is a public institution that symbolizes authority and respect for social order-values that are often shared by those with a conservative worldview (Oberwittler and Roché 2018).

Table 2. Logistic regression analysis of reported trust in the police.

\begin{tabular}{ccc}
\hline AIC: 2596.6 & & \\
\hline & $\operatorname{Pr}(>|\mathrm{z}|)$ & Odds Ratio (OR) \\
\hline Political orientation & & \\
Left-wing & $0.014^{* *}$ & -1.36 \\
Centrist & ref & ref \\
Right-wing & ns & ns \\
\hline Police contacts & & \\
Self-initiated contacts & $0.069^{*}$ & -1.24 \\
Police summonses & $0.021^{* *}$ & -1.71 \\
Police stops & $<0.001^{* *}$ & -2.14 \\
No contact & ref & ref \\
\hline
\end{tabular}


Table 2. Cont.

\begin{tabular}{|c|c|c|}
\hline \multicolumn{3}{|l|}{ AIC: 2596.6} \\
\hline & $\operatorname{Pr}(>|z|)$ & Odds Ratio (OR) \\
\hline \multicolumn{3}{|l|}{ Economic resources } \\
\hline Less than $€ 1800$ & $0.044^{* *}$ & -1.36 \\
\hline Between $€ 1800$ and $€ 2500$ & ref & ref \\
\hline Between $€ 2500$ and $€ 4000$ & ns & ns \\
\hline More than $€ 4000$ & ns & ns \\
\hline \multicolumn{3}{|l|}{ Age } \\
\hline Under 29 & $0.007^{* *}$ & -1.61 \\
\hline 30-39 & $0.079 *$ & -1.31 \\
\hline $40-49$ & ref & ref \\
\hline $50-59$ & ns & ns \\
\hline Over 60 & ns & ns \\
\hline \multicolumn{3}{|l|}{ Religion } \\
\hline Catholic & $0.003^{* *}$ & 1.39 \\
\hline Muslim & $0.044^{* *}$ & -1.57 \\
\hline No religion & ref & ref \\
\hline Protestant & ns & ns \\
\hline Other & $0.092 *$ & -1.55 \\
\hline
\end{tabular}

Source: Pratiques et représentations face à l'État: study conducted in February 2017 by a research team from ELIPSS/CDSP. Sample: All respondents $(\mathrm{N}=2612)$. Significance: ** indicates that the parameter is statistically significant at a confidence level of $5 \%(p<0.05),{ }^{*}$ indicates a confidence level of $10 \%(p<0.1)$, and "ns" indicates that the parameter is not statistically significant. Interpretation: In this logit model, probabilities are assigned in relation to a reference parameter. Thus, a respondent who states that their political orientation is "left-wing" is 1.36 times less likely to express trust in the police than another who identifies as "centrist".

Economic resources also play a part: all other things being equal, individuals who earn less than $€ 1800$ per month are $1.36(p=0.044)$ times less likely to express trust in the police than those in the next income bracket. For those at the bottom of the social scale, public institutions are often felt to be on the side of life's "winners" (Ceka and Magalhães 2019).

Young people are less trusting of public institutions than their elders are, but this disaffection is more entrenched and hostile when it comes to the police. All other things being equal, those aged between 18 and 29 are 1.61 times $(p=0.007)$ less likely to trust the police than those aged between 40 and 49 .

Religion is also an important source of trust or distrust in the police. All other things being equal, Catholic respondents are $1.39(p=0.003)$ times more likely than those of no religion to express trust in the police. Since the logistic regression model controls for the effect of direct contact with the police, this result does not mean that the police behave differently according to the religion of the governed people. Catholics tend to place more value than those of no religion on authority and social order, which could contribute to their stronger attachment to the police (Raison du Cleuziou 2014). In contrast, identifying as Muslim seems to have the opposite effect: all other things being equal, Muslim respondents are $1.57(p=0.044)$ times less likely to express trust in the police than those of no religion. Muslims' distrust in the police may be connected to the fact that they are frequently singled out in public debate (Mayer et al. 2020) and are more often discriminated against by this institution (Jobard 2006). The growing perception among Muslims that they are treated unfairly by the police (Gauthier 2010) can be considered as an explanation of their tendency to express distrust toward the police.

From Table 2 we can clearly identify a negative effect of police contacts on trust. The strongest predictor of distrust is police stops. Individuals who have experienced police stops are, all things being equal, $2.14(p \leq 0.001)$ times more likely to express distrust toward the police than individuals who have not experienced any police contacts in the last two years. Being summoned to a police station also appeared to be significantly associated with distrust in the police. Finally, even self-initiated contacts affect trust in the police. Although the effect on trust is less substantial than for other types of police encounters, people who 
have filed a complaint or asked for a police intervention are $1.24(p=0.069)$ times less likely to express trust in the police than people who have had no contacts with the police. The quantitative results presented above call for the application of a qualitative approach in order to understand why contact with the police fosters distrust of this institution.

\subsection{The Construction of Distrust: A Qualitative Approach to Trust Based on Life History Interviews}

Our qualitative data collected through participant observation makes it possible to describe direct interactions between governed people and the police. Of course, people who self-initiate contact may be different from those who encounter the police involuntarily. Here, we would like to draw attention to two dimensions of interactions with the police that might explain the relationship of distrust that results from these experiences: the production of docility among complainants in the police station and complainants' dependence on the police to obtain recognition of the harms that they have suffered.

\subsubsection{Temporality and Discipline in Police Stations}

The docility of visitors is obtained by the highly regimented way in which police officers receive members of the public in police stations. To grasp this fully, we must pay attention to the signals that police officers give out (Dubois 2016).

The central police station is entered through a security vestibule, on the other side of which is a uniformed officer who asks all visitors the reason for their visit. Yellow strips on the floor indicate where complainants should stand, and adherence to this system is rigidly enforced in order to maintain a safe distance between complainants and the reception desk. Using formal language and a harsh tone, armed and uniformed officers address complainants through commands, demanding to see their identity cards or directing them to take a seat in the waiting room. This behavior is the product of professional socialization focused on safety concerns. During their training, police officers learn to perceive every new event as a potential danger, and they acquire a culture centered on the use of coercion (Crank 2014; De Maillard and Jobard 2015). We observed a track-suited man of about 20 years old who arrived in a visibly agitated state and who explained that he had been the victim of identity theft. The officer addressed him brusquely, ordering him to behave calmly and to take off his hat and sunglasses, which were hiding his face, so as to present himself in a proper way. Through this show of institutional authority, visitors are immediately intimidated, and this colors their perception of the police. A young man, a teacher at a vocational secondary school coming to the police station for the first time, told us of his impression that the police command a special respect: "It's weird-it's a public service, but there's still a certain deference. They're the police, after all", he mused in the waiting room after he had explained his problems to the reception officer. Any kind of protest or irritation is swiftly dealt with by ejecting the complainant, and every time someone is brought into line in this way, the others take note and their deference intensifies. Consequently, most people show a high degree of deference when addressing police officers. While waiting alongside visitors, we observed that anyone irritated by the wait or anxious to know how much longer they might be waiting avoided asking overly direct questions for fear of aggravating the officers, preferring instead to approach the reception desk to ask politely if their presence and request have been duly noted.

Stepping into a police station inevitably involves becoming subject to the institution's temporality. The wait is long-anything between about thirty minutes and several hours. We often observed conflicts between complainants' time constraints and the temporality of the police institution. Sitting on the bench in the waiting room, they often looked at their watch, explaining to us that they had to go back to work or to pick up their children at school or, more prosaically, that they were simply eager to go out shopping instead. One of them expressed an intense frustration at having to wait, as he had taken a day off from work, which he did not want to spend in carrying out administrative procedures. In addition to the long wait, the organization of the complaint service is opaque, which makes it difficult for complainants to understand the institution's temporality. Visitors, 
lacking any clear idea of the order of people's turns or of how long the currently ongoing interviews will last, are stripped of their control of their own time and have no way of knowing just how long they will need to sit and wait for their turn to be called.

Our time spent waiting alongside complainants allowed us to observe that the way in which people experience their time in a police station waiting room varies depending on their social background, the nature of their complaint, and their recollections of using other public services in the past. Some of the people we spoke to were used to dealing with social services and accustomed to waiting; this was the case for one woman who had come to file a complaint against her husband for harassment. In our first conversation, she seemed resigned to having a long wait ahead of her and drew a parallel with previous experiences in other public service waiting rooms. In fact, as a recipient of benefits, she often comes into contact with social services and is obliged to wait before receiving her financial support. In contrast, on the same day, we met a bank employee in his early thirties who clearly lacked this woman's patience. He had come to the police station to report damage to his vehicle in order to make an insurance claim. He railed against the police's inefficiency, comparing their practices with those of companies such as his own, where everything (in his view) is designed around customer service. Waiting is experienced differently depending on the type of request, the complainant's previous encounters with public services in other settings, and the value placed on the time that an individual is prepared to devote to the complaint procedure. Those who are used to dealing with public services have already internalized their subordinate status in the bureaucratic relationship, whereas those whose lives seldom come into contact with social bodies find it much harder to accept the temporality of the institution.

\subsubsection{The Cumulative Effect of Negative Experiences}

In a country where it is difficult to move away from the dominant "penal-welfare culture" (Jobard 2017), the likelihood of having disappointing experiences with the police is significant and can tarnish the representation that citizens have of this institution. Among our participants, three clearly expressed their distrust toward the police. One of them is a 33-year-old manual worker who had experienced multiple acts of racism from the police as well as violent police stops. Another, aged 17, had not experienced wrongful stops but had witnessed unfair police practices in his neighborhood. We decided to explore the case of a couple waiting for police intervention in a conflict. Mélanie Maurey is a former care giver who now works in car sales, and her husband Romain works in a scrapyard dismantling used cars. Both are in their thirties. We met them as they were coming to the police station to gather information about an ongoing police inquiry.

The couple expressed a strong distrust toward the institution. According to our logistic model (Table 2), they are among the low-income individuals who are less likely to trust the police. Being at the bottom of the social scale, they are convinced that richer people have privileged access to the police. To illustrate this distrust, she reported during the interview the case of a well-established local craft-worker who had been able to get his son out of trouble multiple times owing to his personal acquaintances in the police. Local stories can thus also contribute to the construction of people's representations of public institutions.

Each new encounter with local law enforcement had further cemented the couple's view that the police do not care about the difficulties faced by those most in need of their protection. During the interview at their home, they explained that they had lived for several years in a poor neighborhood where crime was rife, and Romain had on several occasions witnessed the ineptitude of the local police force. Although they do not see the police as a repressive force, Mélanie is convinced that the police are more a constraint than a protective force, based on the abusive police stops that she has experienced while driving. This impression appeared to be particularly reinforced a few years later, when Romain fell victim to a scammer. They reported the theft of his checkbook to the police, but the slow pace of the investigation and compensation process made them lose all faith in the institution: 
Mélanie: There are more urgent affairs? We lost 1700 euros, some lose their lives ... I understand that there are more urgent affairs. So, we wait, we wait ... Often, we explain our story again and again to policemen on the phone because we don't know who is the person in charge of our case, not even his ID [Collar number]. Every time I go to the police station, I have to go through the front desk, explain again, only to be answered with: "well sorry we don't have any news. We'll call you back." (Interview at Mélanie and Romain's home, 11 July 2019)

For a low-income couple, the loss of such a sum has serious consequences. Being in a position of dependency on the police services in order to obtain recognition of the damages they have suffered affects their trust in the institution that makes them wait: "Maybe he [the scammer] will pay, but as of today, we've been in a living hell for more than a year." The temporality of the police inquiries and the apparent indifference of the officer at the reception desk reflect, in this couple's view, the image of an institution that has little interest in victims and their personal problems.

\subsubsection{Hesitation about Trusting the Police}

The sociological approach to institutions involves studying both the effects produced by state agencies and the possible lack of their effects (King et al. 2017). Over the long term, trust in the police is the result of multiple and possibly conflicting experiences. Among the respondents interviewed, several of them recounted their hesitation about trusting the police. We chose to focus our study on Florence Mayer, a 50-year-old manager who clearly expressed these deliberations.

We met her while she was filing a complaint about the theft of her bicycle, and she agreed to conduct an interview a few weeks later in a public park after work. Living in an upper-middle-class neighborhood in the city center, she has experienced many incidents of petty crime and antisocial behavior that have gone unpunished. Identifying with the center-left of the political spectrum, Florence does not perceive petty crime as the result of a lack of authority but rather trusts the institutions of the welfare state to maintain social order:

I think that what we need is more social policies, more education ... More than policing, because I think it's a means but not an end. We need to work beforehand with the youth, especially the youth ... (Interview conducted in a public park, 21 June 2019)

In our interview, she did not contest the authority of the police or policing practices. Nonetheless, on the first occasion when she had cause to deal with the police directly, she detected a lack of consideration that caused her to reassess her opinion. On this occasion, after making a complaint against the owner of a dog that had attacked her, she was summoned to the central police station and brought face to face with the guilty party. Having refused any form of compensation, she expected the police to reprimand the owner. Instead, she felt profoundly let down by the tone the officers took with the accused. Feeling disregarded, she left feeling that the harm she had suffered had not been taken into account:

From that day on, I said to myself, "me and the police, we're finished" [laughs].

I had no trust in the police at all... They couldn't care less about the victim and paid much more attention to the culprit.

By failing to take action against the dog owner, the police had convinced Florence that, despite her earlier trust in law enforcement, officers were not at all concerned about her status as a victim. This experience fractured her sense of trust, but further encounters with the police altered her perception yet again. A few years later, after a break-in at her home, she returned to the police station to report what had happened. She recalled:

It was a time when my husband was away. I explained to the police officer that my son was very anxious. He was great, he really reassured him. He knew just what words to use... I thanked him profusely because it was clear he had done a 
good job of making us feel safer... I'm not even sure that's part of his job, actually.

But I did feel reassured! [Laughs]... It restored a bit of my trust in the police.

This second experience profoundly altered Florence's representation of the police, persuading her that it could offer protection, sometimes even beyond its official remit. The empathy shown to her son redeemed the police in her eyes as a public service dedicated to protecting the population.

\subsubsection{The Role of Positive Experiences}

Positive experiences can shake strongly held beliefs. Three participants with negative perceptions of the police developed greater confidence in this institution as a result of positive direct experiences with it. One was a 22-year-old temporary worker who was often in conflict with street police because of his drug use; another was a 47-year-old left-leaning computer scientist who perceived the police as a repressive force. Both ended up trusting the police after the latter came to investigate following burglaries. We decided to explore the case of Nadine Belahmi, a 28-year-old unemployed mother of two, whom we met in the police station, where she had come to file a complaint against her ex-husband for harassment.

This Muslim woman reported having relatives who perceive the police as racist and Islamophobic. Divorced from a violent ex-husband, she had approached the police on a number of occasions, seeking protection from the intimidation and threats she had been experiencing both at home and at her daughter's school gate. Nadine's prior experience with police services had always been positive, and police officers had always taken her side. When her ex-husband turned up armed with a knife at her parents' house, where she was staying at the time, she immediately called the police, who came and arrested him. Consequently, she was very happy with the treatment she had received. Later, she filed a complaint and recalled a policewoman who listened to her and showed concern for her situation. However, she attributes this concern for her welfare to a political context where violence against women is a highly publicized issue ("Right now, there's a lot of talk about battered women, and that context makes the police pay attention..."). Later in the interview, she became much more critical when we talked about the police's response to violent crime in her local area:

Usually, women who go to ask for spousal support and that sort of thing are well looked-after. But when someone is attacked in the street, it's a different story... I know that if I was ever assaulted, I wouldn't go and report it. I would do whatever I had to do to defend myself. Reporting it would take too long, and they wouldn't do anything. Even if there was an investigation, nothing would come of it. (Interview conducted in a coffee shop, 2 July 2019)

Our in-depth interview with this complainant revealed that her relationship with the police is caught up in contradictory tensions. In family matters, she has complete confidence in the police, but she is convinced that officers behave differently toward victims of violence from neighborhoods inhabited by minorities.

In her case, a succession of positive experiences has instilled a strong sense of trust despite her belief that the police are unfair to inner-city youth. Repeated positive experiences can thus influence already entrenched ideas.

\subsection{Social and Individual Recognition in Individual Interviews}

Complaints, like other types of self-initiated contacts, are typical bureaucratic encounters in which individuals turn to authorities to obtain recognition of their status as victims. By being present at individual interviews between complainants and police officers, we observed the everyday distribution of recognition by police officers in their role as streetlevel bureaucrats and, on the complainants' side, the symbolic and emotional challenge of filing a complaint. 
Police officers act as purveyors of the symbolic recognition that can be granted by the state and that has the power to turn simple facts into legally recognized harms. This recognition, in turn, provides access to certain rights. Most of the cases we observed were related to petty crimes or losses arising from the theft of personal property or damage to a vehicle. However, complainants required recognition so that they could claim compensation on their insurance policies. The case mentioned above, regarding Romain and Mélanie, shows that it is not always a simple matter to obtain this symbolic recognition:

Romain: It's been three years since I was told my complaint was being investigated. Since then, I've lost my credit rating and been banned from having a bank account, and meanwhile, he's doing just fine, I mean he's off on holiday!

Police officer: We're dealing with a huge backlog of complaints. These are urgent matters that are piling up, and they're taking up more and more of our time.

Romain: Well, my case might not be urgent, but you don't seem to realize that I have a mortgage to pay, and I need that money. (Participant observation in the police station waiting room, 10 July 2019)

In the absence of legal recognition of the scam of which they were victims, this couple cannot recover the sum that they had lost. While waiting for the police to recognize their situation, they remain deprived of a collective recognition of their status as victims, which would otherwise allow them to seek a refund from their bank.

Police officers are not only representatives of the state but also individuals from whom complainants expect recognition of their dignity. We noted various ways in which police officers can give out signs of indifference, such as making complainants wait, joking inappropriately, or withholding empathy from the victim. We observed the emotional stakes of police-complainant encounters, particularly in domestic violence and harassment cases. Some women who had suffered harassment or violence were anxious about meeting the police and eventually found some relief when police officers empathized with them. After breaking down in tears in the interview room in reaction to the empathy that she had received, this woman suffering from violence from her husband later confided:

I'm sometimes tired of going to the police station, but this time she [the officer] said something very nice like "We won't let you down!". It made me feel good ... you feel considered ... I saw that it's not only about filing papers. (Interview in a coffee shop, 6 July 2019)

In another case of an altercation between a woman in her 30s and her ex-husband, an officer refused to take the side of the complainant and questioned her responsibility in the conflict. While viewing video footage of the quarrel recorded on her mobile phone, the officer criticized the complainant's insults toward her husband and his new partner and ultimately refused to register the complaint. On being denied this recognition, the woman grew angry, and as she left the station, she told us her aggravation at being held partly responsible for the harm inflicted on her.

\section{Discussion}

\subsection{The Negative Effect of Police Contact on Trust in the Police in France}

Our main finding is that police contacts have a negative effect on trust in the police institution in France. Whereas most research focuses on police stops (Tyler et al. 2015; MacQueen and Bradford 2015; Skogan 2017), we were able to show that other types of contacts, such as police summonses and voluntary contacts, also contribute to the erosion of trust in the police.

Our participant observation revealed that beliefs anchored in direct experience of dealing with the police tend to reshape and reorient prior perceptions rather than replacing them. These results suggest that trust should be viewed as an ongoing process that must be reconstructed in order to be properly understood. Interaction with the police is a process 
punctuated by a succession of experiences that continue to occur over the course of a lifetime.

Our qualitative approach to police contacts, which involved asking individuals to relate their various encounters with police services, allowed us to provide an empirical account of the manifestation of trust without reducing the concept of trust to a binary judgment about the police. Our findings have led us to consider trust in the police as an aggregate of practical and symbolic experiences, which are not always clear-cut or uniform. Conversely, adopting a generalized, statistical definition of trust can mask these contradictory tensions. Only by combining quantitative and qualitative methods can we reconstruct the complexity of trust in its various dimensions.

\subsection{The Effect of Social Characteristics on Trust}

The level of trust that an individual invests in the police is dependent on a set of social characteristics that are no different in France than in other countries (Oberwittler and Roché 2018). In our study, it was young people, people with left-leaning political views, low-income households, and Muslims who were least inclined to express trust in the police institution.

There are perceptions that have to do with differing perspectives on social cohesion and maintaining order. In terms of perceptions, there is a gulf between those who value the authority of the police and those who perceive it as a repressive force. Members of the public judge the police based on mental constructs grounded in values that have been laid down over a long socialization process, conventional wisdom, and media discourse but also in any instances of direct contact with the police and in the reported experiences of friends and family. The cases presented here explored only a few aspects of trust in the police in France based on a specific population that already had sufficient trust in this institution to go to file a complaint. Further studies should be carried out in order to provide a more detailed account of the various social contexts in which perceptions of the police develop.

These perceptions of the police are not set in stone but constantly evolve in response to lived experiences of interactions with the law enforcement system and stories related to the police. This result encourages us to further explore the capacity of trust to evolve over an individual's lifetime-especially since age affects feelings of trust-by paying attention to the social context in which trust is expressed.

\subsection{Considering Police Contacts as Instances of Bureaucratic Domination}

Our results indicate that complaints are typical bureaucratic encounters, thereby revealing that the police institution constitutes a social organization (Manning 1977) in which governed people are involved in a relationship of domination.

As our observation showed, the temporality of the police station overrides the individual temporal constraints of the complainants, thus demonstrating the dominant position of the institution. As Pierre Bourdieu reminds us, making someone wait is a common way of exercising power from a distance, by placing that person in a dependent state for as long as they are obliged to remain there (Bourdieu 2000, p. 228). Visitors to a police station are placed in a waiting position and are thereby drawn into an unequal power relationship in which they are conditioned to accept and resign themselves to their dominated status (Auyero 2011).

Several elements of the waiting situation at the police station, such as the requirement to undergo body checks, the system of lines marked on the ground, and the aloof attitude of the police officers at the reception desk, contribute to reinforcing a feeling of distrust that is sometimes already present. Complainants' encounters with formal uniforms and repeated reprimands expose them to a coercive power that discourages them from expressing their anger despite having to endure a long and potentially frustrating wait. In this respect, the police share commonalities with other French administrative institutions, such as immigration services (Spire 2007), but appear very different from social security services, 
in which a greater frequency of confrontational interactions and open conflicts with officers are observed (Dubois 2016).

Observations and individual interviews revealed that members of the public coming to file a complaint are dominated by the institution and that they also depend on it to obtain a social recognition of the harm that has been done to them. The experience of some complainants even resembles that of " $K$ ", the protagonist of Franz Kafka's (2009) novel The Castle, who tries desperately to contact the elusive authorities residing inside the village's castle in order to obtain a recognition of his professional abilities so that the villagers can accept him as the official new land surveyor. The role of the police is not only to steer contentious situations down established legal channels but also to define the status of each of the central protagonists and to identify the victims. The emotional content of police encounters during complaints also suggests that individuals seek an individual recognition of their dignity from police officers. Thus, individuals develop a set of expectations with respect to institutions, similar to those that structure their social relationships with peers (Honneth 1996, p. 92). In their encounters with the police, people expect officers to display certain signs of respect and attention by being polite and showing concern for the problems that they describe.

\subsection{Perspectives on Trust and Limitations of the Study}

In this paper, we relied on qualitative data to provide greater insight into our quantitative results. The observations that we made in police stations and the interviews that we subsequently conducted with complainants are not representative of police contacts in France. A first limitation is that we focused on the production of mistrust, whereas direct contacts between the police and citizens can also produce a relationship of trust. Furthermore, the types of police service that we studied excluded complaints for violent crimes and sexual assault.

The description we have provided of domination in self-initiated contacts does not allow us to propose a generalizable conclusion about the relationship between bureaucratic domination and trust. However, it leads us to consider that the often-lengthy wait imposed on complainants by station officers can be experienced as a lack of concern toward someone in a vulnerable situation and can also be interpreted as an attempt to humiliate them. The complainant's feelings of frustration and dispossession should be taken into consideration when trying to understanding how trust is affected by voluntary contact.

Our observations can help to shed a new light on the debate about trust in the police. Individuals' trust in institutions is partly based on the belief that institutions are capable of acting fairly but also on the particular institution's ability to recognize the validity of the complaints made by individuals and to grant individuals the status of victim, to which they are entitled. The complainant, in their encounter with the police institution, seeks recognition of their dignity and of their status as a victim. By focusing on safety considerations, police officers are unable to respond to these demands, which can add forms of humiliation to the harm already caused. Concepts of justice and fairness do not seem to account sufficiently for the way in which people experience these encounters. We have noted that political and moral judgments about institutions are shaped by practical and symbolic experiences, which have a strong emotional component (Honneth 1996, p. 138). These practical experiences are closely tied to the relations of domination that are played out in the interactions between police officers and governed people. The social value that emerges from the way in which the institution treats each complainant thus appears to be preponderant in the construction of the relationship of trust and distrust.

Author Contributions: Both authors equally contributed to this manuscript. All authors have read and agreed to the published version of the manuscript.

Funding: This research received no external funding.

Informed Consent Statement: Informed consent was obtained from all subjects involved in the study. 
Data Availability Statement: Data are available on request at https:/ / cdsp.sciences-po.fr/fr/ressourcesen-ligne/ressource/fr.cdsp.ddi.elipss.2017.01.preface/.

Conflicts of Interest: The authors declare no conflict of interest.

\section{References}

Auyero, Javier. 2011. Patients of the state: An ethnographic account of poor people's waiting. Latin American Research Review 46: 5-29. [CrossRef]

Boda, Zsolt, and Gergő Medve-Bálint. 2017. How perceptions and personal contact matter: The individual-level determinants of trust in police in Hungary. Policing and Society 27: 732-49. [CrossRef]

Bourdieu, Pierre. 2000. Pascalian Meditations. Translated by Richard Nice. Palo Alto: Stanford University Press.

Bradford, Ben, Jonathan Jackson, and Elizabeth A. Stanko. 2009. Contact and confidence: Revisiting the impact of public encounters with the police. Policing and Society 19: 20-46. [CrossRef]

Ceka, Besir, and Pedro C. Magalhães. 2019. Are the rich and the poor equally committed to liberal democracy? Socioeconomic status, inequality, and the political status quo. Comparative Politics 52: 383-412. [CrossRef]

Crank, John P. 2014. Understanding Police Culture, 2nd ed. New York: Routledge.

De Maillard, Jacques, and Fabien Jobard. 2015. Sociologie de la Police. Politique, Organisation, Réformes. Paris: Armand Colin.

Dubois, Vincent. 2016. The Bureaucrat and the Poor: Encounters in French Welfare Offices. London: Routledge.

Gauthier, Jérémie. 2010. Esquisse du pouvoir policier discriminant. Une analyse interactionniste des cadres de l'expérience policière. Déviance et Société 34: 267-78. [CrossRef]

Honneth, Axel. 1996. The Struggle for Recognition. The Moral Grammar of Social Conflicts. Translated by J. Anderson. Cambridge: MIT Press.

Jackson, Jonathan, and Ben Bradford. 2009. Crime, policing and social order: On the expressive nature of public confidence in policing. British Journal of Sociology 60: 493-521. [CrossRef] [PubMed]

Jobard, Fabien. 2006. Police, justice et discriminations raciales. In De la Question Sociale à la Question Raciale. Paris: La Découverte, pp. 211-29.

Jobard, Fabien. 2017. Transformation of State's Use of Force in Europe. In Reconfiguring States in Crisis. Oxford: Oxford University Press, pp. 353-76.

Johnson, Devon, Edward R. Maguire, and Joseph B. Kuhns. 2014. Public perceptions of the legitimacy of the law and legal authorities: Evidence from the Caribbean. Law and Society Review 48: 947-78. [CrossRef]

Kafka, Franz. 2009. The Castle. Translated by Anthea Bell and Edited by Ritchie Robertson. Oxford: Oxford World's Classics.

King, Desmond, Patrick Le Galès, and Tomaso Vitale. 2017. Assimilation Security, Borders in the member States. In Reconfiguring States in Crisis. Oxford: Oxford University Press, pp. 428-50.

Li, Yudu, Ling Ren, and Fei Luo. 2016. Is bad stronger than good? The impact of police-citizen encounters on public satisfaction with police. Policing: An International Journal of Police Strategies and Management 39: 109-26. [CrossRef]

MacQueen, Sarah, and Ben Bradford. 2015. Enhancing public trust and police legitimacy during road traffic encounters: Results from a randomised controlled trial in Scotland. Journal of Experimental Criminology 11: 419-43. [CrossRef]

Manning, Peter K. 1977. Police Work: The Social Organization of Policing. Cambridge: MIT Press.

Mayer, Nonna, Guy Michelat, Vincent Tiberj, and Tomaso Vitale. 2020. Permanences et mutations de l'antisémitisme et de l'islamophobie. In La Lutte Contre le Racisme, L'antisémitisme et la Xénophobie. Paris: La Documentation française, pp. 76-91.

Myhill, Andy, and Ben Bradford. 2012. Can police enhance public confidence by improving quality of service? Results from two surveys in England and Wales. Policing and Society 22: 397-425. [CrossRef]

Oberwittler, Dietrich, and Sébastien Roché. 2018. Towards a broader view of police-citizen relations: How societal cleavages and political contexts shape trust and distrust, legitimacy and illegitimacy. In Police-Citizen Relations across the World: Comparing Sources and Contexts of Trust and Legitimacy. New York: Routledge, pp. 3-26.

Raison du Cleuziou, Yann. 2014. Qui sont les Cathos Aujourd'hui? Paris: Desclée de Brouwer.

Reisig, Michael D., and Meghan S. Chandek. 2001. The effects of expectancy disconfirmation on outcome satisfaction in police-citizen encounters. Policing: An International Journal 24: 88-99. [CrossRef]

Reiss, Albert J. 1971. The Police and the Public. New Haven: Yale University Press.

Roché, Sébastien. 2016. De la Police en Démocratie. Paris: Grasset.

Roché, Sébastien. 2017. Trois concepts clés pour analyser la relation police-population: Confiance, légitimité et justice procédurale. Paris: Cahiers de la Sécurité et de la Justice, Revue de l'Institut National des Hautes études de la Sécurité et de la Justice, pp. $103-11$.

Rosenbaum, Denis P., Amie M. Schuck, Sandra K. Costello, Darnell F. Howkins, and Marianne K. Ring. 2005. Attitudes toward the police: The effects of direct and vicarious experience. Police Quarterly 8: 343-65. [CrossRef]

Skogan, Wesley G. 2005. Citizen satisfaction with police encounters. Police Quarterly 8: 298-321. [CrossRef]

Skogan, Wesley G. 2006. Asymmetry in the impact of encounters with the police. Policing and Society 16: 99-126. [CrossRef]

Skogan, Wesley G. 2017. Stop-and-frisk and trust in police in Chicago 1. In Police-Citizen Relations across the World: Comparing Sources and Contexts of Trust and Legitimacy. Abingdon: Routledge, pp. 247-65.

Spire, Alexis. 2007. L'asile au guichet. La dépolitisation du droit des étrangers par le travail bureaucratique. Actes de la Recherche en Sciences Sociales 169: 4-21. [CrossRef] 
Spire, Alexis 2020. La confiance dans l'État: Une relation pratique et symbolique. In Crises de confiance. Paris: La Découverte, pp. 37-55. Stack, Steven, and Liqun Cao. 1998. Political conservatism and confidence in the police: A comparative analysis. Journal of Crime and Justice 21: 71-76. [CrossRef]

Tyler, Tom R. 1990. Why People Obey the Law. New Haven: Yale University Press.

Tyler, Tom R. 2011a. Trust and legitimacy: Policing in the USA and Europe. European Journal of Criminology 8: 254-66. [CrossRef]

Tyler, Tom R. 2011b. Why People Cooperate: The Role of Social Motivations. Princeton: Princeton University Press.

Tyler, Tom R., and Yuen J. Huo. 2002. Trust in the Law: Encouraging Public Cooperation with the Police and Courts. New York: Russell Sage Foundation.

Tyler, Tom R., Jonathan Jackson, and Avital Mentovich. 2015. The Consequences of Being an Object of Suspicion: Potential Pitfalls of Proactive Police Contact. Journal of Empirical Legal Studies 12: 602-36. [CrossRef]

Van Craen, Maarten, and Wesley G. Skogan. 2014. Trust in the Belgian police: The importance of responsiveness. European Journal of Criminology 12: 129-50. [CrossRef]

Van Damme, Anjuli. 2017. The impact of police contact on trust and police legitimacy in Belgium. Policing and Society 27: 205-28. [CrossRef]

Vitale, Tomaso. 2009. Politique des évictions. Une approche pragmatique. In Sensibilités Pragmatiques. Enquêter sur l'action Publique. Bruxelles: P.I.E. Peter Lang, pp. 71-92.

Wacquant, Loïc. 1993. Urban outcasts: Stigma and division in the black American ghetto and the French urban periphery. International Journal of Urban and Regional Research 17: 366-83. [CrossRef]

Waddington, Peter A. J., Kate Williams, Martin Wright, and Tim Newburn. 2015. Dissension in public evaluations of the police. Policing and Society 25: 212-35. [CrossRef]

Wilson, James Q. 1968. Varieties of Police Behavior. Cambridge: Harvard University Press.

Wu, Yuning, and Ivan Y. Sun. 2009. Citizen trust in police: The case of China. Police Quarterly 12: 170-91.

Yesberg, Julia A., and Ben Bradford. 2018. Affect and trust as predictors of public support for armed police: Evidence from London. Policing and Society 29: 1058-76. [CrossRef]

Zhang, Shan-gen, Liquin Cao, Yuning Wu, and Feng Li. 2018. Demystifying confidence in different levels of the police. Policing and Society 30: 241-54. [CrossRef] 